\title{
Impact of Firm Size on Earnings Management; A Study of Textile Sector of Pakistan
}

\author{
Usman Ali \\ MS Business Administration National University of Modern Languages (NUML) Islamabad, Faisalabad Campus \\ Muhammad Afzal Noor \\ Lecturer Department of Management Sciences \\ National University of Modern Languages (NUML) Faisalabad Campus \\ Muhammad Kashif Khurshid \\ Lecturer Department of Management Sciences \\ National University of Modern Languages (NUML) Faisalabad Campus \\ Akhtar Mahmood \\ MS Business Administration National University of Modern Languages (NUML) Islamabad, Faisalabad Campus
}

\begin{abstract}
The study was conducted to evaluate the impact of firm size on earnings management for the textile sector of Pakistan. For this purpose annual ten years data was obtained from 2004 to 2013 for fifty selected firms from the textile sector of Pakistan. Natural logarithm of total assets was used as the proxy of firm size. On the other hand earning management was the dependent variable of this study. Earnings management was measured through discretionary accruals by using modified Jones model. Descriptive statistics, correlation and panel data analysis was used for capturing the impact of firm size on earnings management. The statistical results of this study revealed that there is positive and significant impact of firm size on earnings management.
\end{abstract}

Keywords: Firm Size, Discretionary Accruals, Earnings Management, Karachi Stock Exchange

\section{INTRODUCTION}

Different views exist regarding the relationship of earning management with firm size. First the firm size relates to the internal control system; large the firm size less the earning management. The large firms have the more effective internal control system and team of qualified and competent auditors than the firms that are small in size. It leads to the reliability of its financial statements to public (Warfield, Wild et al., 1995). Second, audit of large firms was carried on by the large five firms that have the most competent and qualified team of auditors to audit the firms; which provide help to prevent earning management. Quality differentiation arises among big accounting firms on controlling, aggressive and opportunistic earning management in national, international firms (Francis, 1999). Third, the firms that are large in size have more funds to utilize the best technology and expertise to generate in time financial information to public. Therefore, the large sized firms manage their earning less as compared to small sized firms by keeping in view its reputation and cost in the existence of financial analysts.

Opposing views suggest that large sized firms manage its earning more as compared to the companies that are small in size. Barton and Simko (2002) revealed in their study that the large sized firms have to manage their earnings due to the more pressure of investors and to meet the expectations of analysts. Myers and Skinner (2007) studied the earnings growth of firms for 14 quarters and they notified the fact that the large firms do not show their real earnings.

Large companies are more proficient to negotiate with auditors. As large the firm size more will be the negotiation power of the firm. Nelson, Elliott and Tarpley (2002) argued that the large firm's earning management practices were ignored by the auditors. Third, large sized firms have more accounting treatments for a transaction and more current assets. It indicates that large size firms are more able to manage their earnings than small firms. Despite strong internal control system in large sized firms its management violates its system to report its earning as it desired. Big firms manipulate their earnings to reduce political cost. The benefits and skills to organize the earning change with the size of the firm.

The firm size was computed by taking the Log of total assets of the company. Burgstahler and Dichev (1997) reported that earning management practices are more prevalent among large and medium sized firms than small firms. They estimated that $8-12 \%$ of firms manipulate earnings to increase their earning while on the other hand almost 30-44 \% firms manage their earning to report positive earning. The relation of earning management with firm size remains unexplored and unknown. In this study this unexplored relation is studied.

Earning represents the 'net profit' or 'net income' of the firm. Healy and Whalen (1999) stated "earning management occurs when managers use their judgment in financial reporting and in structuring transactions to alter financial reports to either mislead some stakeholders about the underlying economic performance of the 
company or to influence contractual outcomes that depend on reported accounting numbers".

The proprietary cost theory presented by the Verrecchia (1983) supports the idea of earning management and firm size. This theory states that large firms are easily scrutinized by investors and regulators as compared to small firms. The managers of large firms realize that the cost of supplying non-proprietary information to public is minimal as compared to the managers of small firms. The large firms engage in the less earning management while the smaller firms manage their earnings more. From an economic angle the firm's size determine the family's ability to exert powers and dominate the family firms. There are different incentives and behaviors, large and small firms have with regard to earning management.

Jensen and Meckling (1976) presented the agency theory. This theory explains the relationship of principal and agent. Principal the person who assigns some decision making powers to the agent and the agent is the person who performs some services on principal's behalf. Both parties have the same goal but different interests and to achieve own interests; agent may act harmfully in the principal's interest. The relationship of stockholders and managers within the firm fits the pure agency relationship definition. Financial analysts use financial information provided by the company to assess its current financial status and on the base of these figures they predict the future performance of the company. These key figures are future earnings and sales. They use these figures as benchmark for future. It is necessary for managers to achieve these benchmark figures if they fail to achieve the stock prices of their firms that may decline in the market.

The remuneration of top management is highly attached with the large stock prices. Matsunaga and Park (2001) stated that the bonus of CEO is negatively affected if firm's reported earnings is below the analysts forecasting. Consequently managers have the incentives to manage the earning to achieve the analysts forecasting.

An effort was made in this study to evaluate the effect of firm size on earning management. Firm Size was calculated by taking the Log of total assets. Earning management was calculated through discretionary accruals (DA). The discretionary accruals (DA) were calculated through the Jones Model.

\section{Research Objectives}

- To find the impact of firm size on earnings management.

- To find the relationship between firm size and earnings management.

- To find the direction of relationship between firm size and earnings management.

\section{LITERATURE REVIEW}

\subsection{Impact of Firm size on earning management}

Naz et al. (2011) obtained the annul data for 5 years from the 74 sample companies to check the impact of firm size and capital structure on earning management. They selected the sample firms from sugar, cement and chemical sector. Total assets were used as proxy to determine the firm size. For measuring the capital structure gearing ratio was used as proxy. Earning management was measured through the discretionary accruals by using the Jones Model. The conclusion of studies showed that the capital structure inversely correlated with earning management. They further concluded that the firms having the high amount of debts have creditors as watch dog on its earning management practices. Moreover the study revealed that size of firm positively related to earning management.

Rahmani and Akbari (2013) identified the association of size of firm and capital structure with the management of earning in Iran. 90 firms were selected as sample from the total listed firms on Tehran Stock Exchange to gain the secondary data over the period of 2008 to 2012. Discretionary accruals were used as proxy to measure the earning management. Discretionary accruals were calculated through Modified Jones model. Total assets logarithm was used as tool for the computation of firm size. Gearing ratio was used to measure the capital structure. The study indicated the significant positive effect of firm size and capital structure on earning management. It revealed that the firms having the more debt based capital structure have the creditors as watch dog to discourage the practices of earning management.

Paiva and Lourenço (2013) attempted to discover the association of size of firm with earning management in family firms. The dependent variable of this study was earning management. It was calculated through proxy of discretionary accruals. Discretionary accruals were computed by using the Jones model. Independent variables of this study were the size of family firms. Family firm in this study was defined as the firm whose $25 \%$ equity is owned by the family and one representative is officially concerned with the authority of an organization. Secondary data from 2006 to 2010 was collected from the non-financial sector. This study concluded that the family firms that are large in size have the lower level of earning management while on the other hand the small family firms have the large level of earning management. Gong, Li et al., (2009) gave an idea about the techniques used to manipulate the earning of the firm. Moreover the causes which stimulate a manager to alter the real figures of financial statements were also discussed. Three techniques were clarified in this research by using which the managers manage the earning of the firm. The first technique that a company use to manipulate its earning is based on the accruals. The amount of accruals was obtained by deducting the operational cash flow from the net income of the firm. For instance when goods are sold on credit basis this type of transaction creates the accrual of revenue. These accruals are known as the non-discretionary accruals. When company intends to manage its earning it may 
increase or decrease these accruals. In addition the income of the firm may be altered by changing the value of discretionary accruals like the reserves of bad debts, the cost of warranty and the written down of inventories. The second way to manage the income is based on the real transaction. In this type the income is managed by structuring the actual activities of business and time. The third type of managing the earning is to put the efforts to shift downward expectations of analysts. This type reflects the management of expectations. Study also discovered that the managers of firms receive many types of incentives to show the earning figures which is up to the expectation of analysts.

Siregar and Utama (2008) conducted study in Indonesia to analyze the relationship of corporate governance, firm size and ownership structure with earning management. The firms listed in the Jakarta Stock Exchange were considered as population for data collection. Multiple regression tests were applied to withdraw the results. The study showed positive relationship of family ownership firms with earning management. It showed that the family firms perform more practices of earning management than the firms having little portion of family ownership. On other side the study found no evidence on the relationship of organizational rights, size of the firm, and corporate governance with the earnings management.

Peni and Vähämaa (2010) observed the role of gender to carry out the practices of earning management in this research work. To measure the earning management discretionary accruals proxy was used which was calculated by using the two models. The gender of high authorities like CEO and CFO was considered to precede the study. First model used to measure the earning management in this study was proposed by the Dechow and Dichev (2002) and the second model was anticipated by the McNichols (2002) as modified DD model. Secondary data was obtained from the year 2003 to 2007. Panel regression was run to take out the results. The results of this study revealed that the firms having the female chief financial officer show the decreasing discretionary accruals value; because female CFO's adopt more conservative financial reporting strategies.

Kim et al. (2003) studied to check the association between earning management and firm size. He got the 18 years data of large, medium and small firms. Aim of research was to discover the relation of earning with the size and market value at the start of the year. Study showed that the size of firms have the strong effect on the earning management of the firms. Moreover the study also showed that the firms that are small in size manage their earning less than the firms that are large in size. In simple words big firms manage their earning more than the medium and small sized firms.

Moss and Stine (1993) studied to check the importance of firm size with cash conversion cycle in days. This showed that the size of the firm is an imperative factor to compute the days of cycle of cash. The study revealed that the firms big in size lead to the shorter of cash conversion cycle. In addition it concluded that days of cash cycle move in the same direction with the ratios of working capital.

Llukani (2013) established the evidence on the association of size of firm and management of earning in Albanian market. Logarithm of total assets was used as proxy to measure the size of the firm. Discretionary accruals were computed as a proxy of earning management in this work. Discretionary Accruals were calculated by means of the Jones model. He selected 75 firms from private sector to obtain the secondary data from the year of 2009 to 2011 . The results of the study were obtained by applying the regression analysis which showed that the companies whether they are small or large in size manage their returns to hide their losses or to show the positive trend in their earnings.

Swastika (2013) carried out study to evaluate impact of corporate governance and firm size on earning management for beverage and food companies in Indonesian Stock Exchange. Secondary data was obtained from the 51 foods and beverage companies from 2005 to 2007. Size of firm was measured by taking the log of sum of assets. Earning management was measured through the discretionary accrual by the Jones model. The board of directors, audit quality and board independence were used as proxies to measure the corporate governance. Multiple regression tests were applied to extract results. The results of this study revealed that corporate governance like number of directors is positively associated with management of discretionary accruals. While the size of board is negatively connected with earning management. Study also concluded that firm size has the opposite influence on earning management in food and beverages companies in Indonesia Stock Exchange.

Shaheen and Malik (2012) analyzed the intensity of capital, profitability of firms and the size of firms to know their relation with the financing of debt. The source of data collections was the financial reports of sampled companies. The debt financing was computed by using the ratio of debt to capital. The capital intensity was obtained by dividing the average total assets to sales. The log of total assets was taken to calculate the size of firms. The profit of companies was determined through the ratio of gross profit margin to sales. The conclusion of the study showed that the intensity of capital, profit of firms and the size of firms effects to the debt financing of firms.

Attari and Raza (2012) analyzed the optimal conversion of cash cycle to identify its movement with regard to the firm size and profit of firms. Cash conversion cycle was taken as the independent variable in this work. This cycle was computed by summing up the days of inventory and account receivable and subtraction of accounts payables in days. Total assets and the revenue of sales were considered to quantify the value of the size of the firm. Five years secondary data i.e. 2006 to 2010 was obtained from the sectors including the; automobile 
and parts, chemical, food products and cement. The results from the study were extracted by using the statistical techniques of Annova and Pearson correlation. The conclusion of study revealed the movement of days of cash cycle in the opposite direction of firm size. It further suggested that the large firms manage their cash conversion cycle efficiently as compared to small firms. On the other hand results also showed the significant positive association of return on assets and the profit percentage on cash cycle.

Hribar and Jenkins (2004) conducted study to evaluate the causes of changing in the estimated cost of capital and earning of firms on account of restatement of accounting. The sample of 919 restatement incidents from Jan1, 1992 to June 30, 2002 were taken to perform this research work. The results of this study showed that firm value is more concerned with cash flow and risk effect. It also showed that earning restatements enhances the uncertainty about manager's credibility, management competence and the overall perception of earning quality and increases their required rate of return. Moreover, the study indicated that the interpretations started by the auditors basis to increase in the cost of capital.

Osazevbaru (2012) discovered the relation of creative accounting with the value of firm. He determined the firm value by dividing the net operating income by overall capitalization rate. For creative accounting he used the seven variables like recognizing premature or fictitious revenue, getting creative with income statements, aggressive capitalization and extended amortization, exaggerated non-recurring items, selling off low bases assets, under accruing expenses, intentional minor breaches. The primary data was collected from the 10 chartered accounting and stock broking firms through the questionnaire. The study concluded that the investors remain unable to depict the real picture of the firm through financial statements showed by the managers. The study showed the significant positive impact of creative accounting on the firm value. It further indicated that the techniques used to create the accounts enhanced the value of the firm.

Ahmadi and Arasi (2012) explored the relationship of capital structure with earning management with reference to Chinese capital market. The data for the period of 2003 to 2007 was obtained from the sampled firms of Shanghai Stock Exchange. The study showed that firms manage their earning more if equity proportion is less in their capital structure due to the opposite connection of both. Moreover the study concluded that firms having the more debt in their capital structure perform more practices to manage their earning due to the strong positive relation of both variables.

Park and Shin (2004) conducted study in Canada to check the impact of board composition on earning management. Earning management was used as dependent variable in this study. It was calculated by discretionary accruals as proposed by the Jones in 1991. Board composition was taken as independent variable in this study which was measured through the ratio of members from outside board, members of financial intermediaries in the board, institutional shareholders, number of members in the board and the ownership concentration. Regression analysis was run to withdraw the results of the study. This study found no evidence on the relation of members of board from outside with the management of earning. It implied that the outside members are not helpful in monitoring the earning management practices.

Myers et al. (2007) conducted research to look at the association of management of earning with the earning per share. The Sample of 647 firms was taken who's claimed EPS much higher as expected. It was argued that the managers have the strong benefit by not disclosing the decrease in EPS. It was also argued that by changing the outstanding shares, repurchases of shares and more the tax rates are inversely related to increase the earning. The firms that reported high increase in EPS their profits are abnormal. The earning of such firms was more than the last year even than expected earnings. The managers of these firms used their discretionary methods to declare their smooth earning. It was also disclosed in this study that the managers increase their firm stock repurchase to report the increase in EPS.

Yuan and Zafar (2010) conducted a comparative study between China and Pakistan to examine the dividend payout ratio and its connection with the practices of earning management. The study was conducted to take the sample of fifty five companies of China and 120 of the companies of Pakistan. Secondary data from the year 2001-2007 from Pakistan and 2003-2007 from China was collected through their published reports. They measured the dividend payout by dividing the dividend paid by net profit after tax. To measure the earning management they used the discretionary accruals. These were calculated by using the Jones model. Study indicates that the large companies in Pakistan pay more dividend as their size is positively correlated with the dividend. In China there is inverse relationship between firm size and dividend ratio. The Chinese companies that are small in size pay more dividends. Furthermore they concluded that the discretionary accruals have significant impact on the dividend payout ratio.

Kim et al. (2003) identified the relationship of earning management with size of firm. They selected sampled firms from the companies whose financial statements were available on the commutate data base from 1983 to 2000. They calculated the earning by dividing the net income with beginning market value and change in income measured by dividing the last year earning less current year earning divided by closing market value. The results of this research revealed that the practices of earning management increase with the increase of size of firms. They provided the evidence that the small firms manage earnings to hide their losses. The firms large in size 
manage the earnings aggressively to smooth the earning and to show the positive change in earnings.

Tabassum et al. (2013) discovered the practices of management of earning in the firm and their effect on the subsequent financial performance of the firm. They used three measures for earning management and four measures for financial performance. Return on equity (ROE), price to earnings ratio (PE) and earnings per share (EPS) were used for financial performance. Earning management was measured by three different types like reduction in discretionary expenses (advertising, research and development expenses and sales and admin expenses), overproduction and sales manipulation. In this study the data was obtained from 2007 to 2011 from 117 sampled firm of Pakistan. This research explained the inverse effect of earning management on the financial performance of selected firms. They concluded that the managers put efforts to manipulate financial statements to show smooth and good financial performance.

Ball and Shivakumar (2006) studied the function of accruals at the time of loss recognition and gains of the firms. Two roles of accruals were clarified in this work. The first role is the change of cash flows on account of change in operating activates i.e. working capital variation like receivables, inventory and payables that vary over time. Working capital helps to provide the numbers that represent the feasible performance of firm to stakeholders. The next function of accruals is in time recognition of the assets and liabilities of working capital and long term assets and liabilities. These two mentioned roles of accruals increase the timeline of earnings.

Alves (2011) explored the relationship of board structure with earning management for companies listed in Portugal. Board structure was measured by the board size, board composition and board monitoring committees. Earning management was used as dependent variable in this study. It was calculated through the discretionary accruals by using the Jones model. OLS regression test was applied to identify the relation of board structure and earning management for thirty four firms of non-financial sector for the five year covering from 2002 to 2007 . The study indicated the inverse association between the variables of board composition and discretionary accruals. Moreover the study found no evidence on the association of audit committee and earning management.

Butt et al. (2009) examined the relationship of corporate governance and earning management in this study. The sample of 53 listed companies out of 100 on KSE 100 index was selected. They measured the corporate governance according to the quality of corporate governance referred by Klapper and Love (2009). Three variables were used to know the quality of governance. These variables were the structure of board, the structure of ownership and the independence of audit committee. Earning management was measured through the discretionary accruals as per the Jones model. The result of their study indicated the significant association between the earning management and variables of governance. As per the outcome of this research the governance enhances with the increasing of discretionary accruals. The study concluded that the decision making power of Pakistani companies improves with smoothing the earning.

\subsection{Development of hypotheses}

After reviewing the literature and identification of dependent and independent variables the following research hypotheses were developed to identify the effect of firm size on earnings management. The firm size was obtained by taking the log of total assets. Discretionary accruals were used to measure the earning management.

\section{Hypothesis 1}

H0 There is no relationship between firm size and earning management.

H1 There is significant relationship between firm size and earning management.

\section{RESEARCH METHODOLOGY}

\subsection{Sampling}

There were 153 textile firm listed in Karachi Stock Exchange in 2013. They were the total population of this study and the sample of fifty companies was selected for this study. This sample is the $32 \%$ of total population and the data was collected from the financial reports of sampled firms for ten years i.e. 2004 to 2013.

\subsection{Data estimation}

By reviewing the literature it has come to know that the accruals are a widely accepted proxy of earning management. Accrual may be calculated by two ways.

- Balance sheet approach

- Cash flow statement approach

(1) Balance Sheet Approach

As per the approach of balance sheet the accruals may be computed as:

$$
\mathrm{TA}_{\mathrm{t}}=\Delta \mathrm{CA}_{\mathrm{t}}-\Delta \mathrm{Cash}_{\mathrm{t}}-\Delta \mathrm{CL}_{\mathrm{t}}+\Delta \mathrm{DCL}_{\mathrm{t}}-\mathrm{DEP}_{\mathrm{t}}
$$

Where;

$\Delta \mathrm{CA}_{\mathrm{t}} \quad$ it indicates the change in current year's current assets

$\Delta \mathrm{Cash}_{\mathrm{t}}$ it refers to change in cash and cash equivalents in current year 
$\Delta \mathrm{CL}_{\mathrm{t}} \quad$ it denoted to the fluctuation in current liabilities in current year

$\triangle \mathrm{DCL}_{\mathrm{t}}$ it indicates the change in the amount of debt included in the current liabilities in current year

$\triangle \mathrm{DEP}_{\mathrm{t}}$ is the expense of depreciation and amortization in current year

\section{(2) Cash Flow Statement Approach}

According to this approach accruals may be computed by using the following formula.

\section{TA -NDA}

Where;

TA

NDA

Total Accruals which are equal to cash flow from operation minus Net Income.

Non-Discretionary Accruals which may be computed in the following way.

Total accruals $/ \mathrm{A}_{\mathrm{t}-1}=\mathrm{a} 1\left[\frac{1}{\mathrm{At}-1}\right]+\mathrm{a} 2\left[\frac{\text { Change in Rev- Change in } \mathrm{A} / \mathrm{R}}{\mathrm{At}-1}\right]+\mathrm{a} 3\left[\frac{\mathrm{PPE}}{\mathrm{At}-1}\right]$

Where;

$\mathrm{A}_{\mathrm{t}-1}$

Change in revenue:

is total assets at the end of year $t-1$

Change in $\mathrm{A} / \mathrm{R}$ :

PPE:

a1, a2, a3, is revenue in year $t$ less revenue in year $t-1$

is net receivable in year $t$ less net receivable in year $t-1$.

is gross property plant and equipment at the end of year $t$.

are firm specific parameters.

Total accruals are computed by subtracting the net income from operational cash flow. At-1 denotes to the value of total assets of the company in last year. Non-discretionary accruals are obtained from the right side of the above equation. The change in the revenue of the company is subtracted from the change in debtors of company. In the end the value of property, plant and equipment is divided on the amount of last year assets.

After calculating the last two components of the right side, regression is run to calculate the value of the intercept. This is adjusted against the total assets of the preceding year. Next coefficients of both revenue and PPE are calculated. These coefficients are adjusted in formula. Adding all the coefficients and intercepts the value of non-discretionary accruals is obtained. At the end the amount of discretionary accruals is obtained by deducting the value of total accruals from the amount of non-discretionary accruals.

By reviewing the literature it was come to know that the most researchers prefer the approach of cash flow statement for the computation of discretionary accruals as compared to the balance sheet approach. Therefore, cash flow statement approach proposed by Jones was used in this study to calculate the discretionary accruals. Logarithm of total assets was taken as proxy to measure the size of firm.

\subsection{Types of analyses}

To check the impact of firm size on earning management the following analyses were used in this research:

- Descriptive statistics,

- Correlation

- Panel data analysis

Descriptive statistics provided the mean values along with range, maximum and minimum values of sample data. It also revealed the standard deviations of the sampled data. Correlation is used to find out the relationship between independent and dependent variables. It was used in this study to find out the relationship between firm size and earnings management.

Panel data analysis is statistical technique used to determine the strength of relationship between one dependent variable and series of independent variables. In this study panel data models were used to find out the impact of firm size on earning management.

\subsection{Estimation Models}

To check the effect of firm size on earning management the following models were developed to apply the panel data analysis.

$$
\begin{aligned}
& \mathrm{EM}_{\mathrm{it}}=\beta_{\mathrm{O}}+\sum_{\mathrm{i}}^{\mathrm{n}} \beta_{\mathrm{i}} \mathrm{X}_{\mathrm{it}}+\varepsilon \\
& \mathrm{EM}=\beta_{\mathrm{O}}+\beta_{1} \mathrm{X}_{1}+\dot{\varepsilon} \\
& \text { Where; } \\
& \beta_{\mathrm{O}} \quad=\text { intercept } \\
& \text { EM = Earning Management } \\
& \mathrm{X}_{1} \quad=\text { Firm size } \\
& \beta_{1}=\text { Coefficient of X1 } \\
& \dot{\varepsilon}=\text { Error }
\end{aligned}
$$




\section{CONCEPTUAL FRAMEWORK}

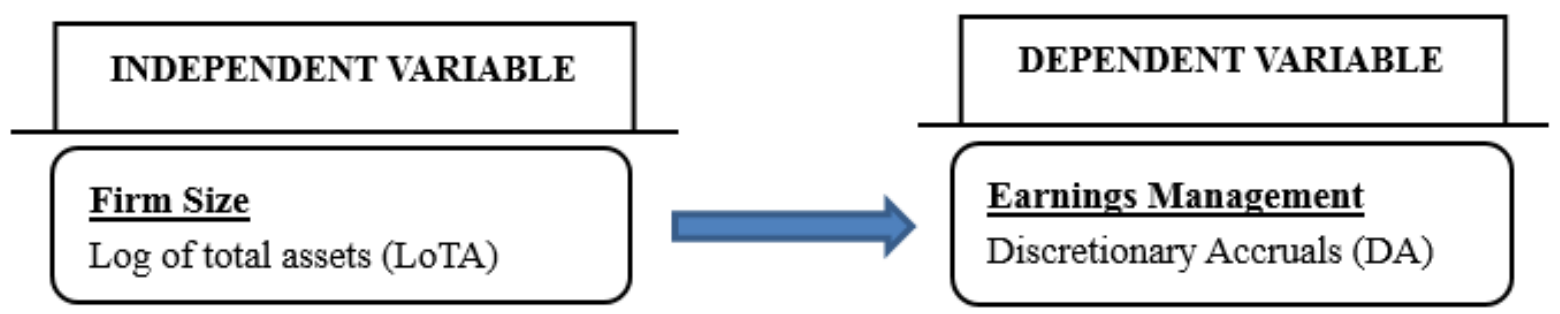

Diagram 1: Impact of Firm Size on Earnings Management

TABLE 3.1

Descriptive Statistics

\begin{tabular}{|l|c|c|c|c|c|c|}
\hline & $\mathrm{N}$ & Range & Minimum & Maximum & Mean & Std. Deviation \\
\hline DA & 500 & 4.87 & -2.83 & 2.03 & 1.13 & 7.37 \\
\hline LOA & 500 & 5.05 & 0.24 & 5.29 & 3.27 & 0.76 \\
\hline Valid N (listwise) & 500 & & & & & \\
\hline
\end{tabular}

\section{Interpretation}

Table 3.1 shows the minimum and maximum values of dependent and independent variables of this study. Earning management is the dependent variable and was measured through discretionary accruals. The minimum value of $\mathrm{DA}$ is -2.83 and the maximum value is 2.03 while the average value is 1.13 with variation of 527.37 . The minimum value of LOA is 0.24 and the maximum value is 5.29 while the average value is 3.27 with the variation of 0.76 .

TABLE 3.2

Correlation Matrix

Interpretation

\begin{tabular}{|c|c|c|}
\hline & D.A & LOA \\
\hline D.A & 1 & \\
\hline LOA & .275 & 1 \\
\hline
\end{tabular}

Table 3.2 shows correlation coefficients of firm size with earning management. The value of LOA in the table is 0.275. It indicates that in textile sector of Pakistan LOA has the significant relationship with earning management. It reveals that the companies having the large amount of assets are engaged more in earning management practices as compared to the companies that have the small amount of assets. This result is similar to the study conducted by Naz et al. (2011) to check the impact of firm size and capital structure on earning management; moreover the results of this study are similar to the Rahmani and Akbari's (2013) conducted to evaluate the impact of Firm size and capital structure on earning management in Iran. 


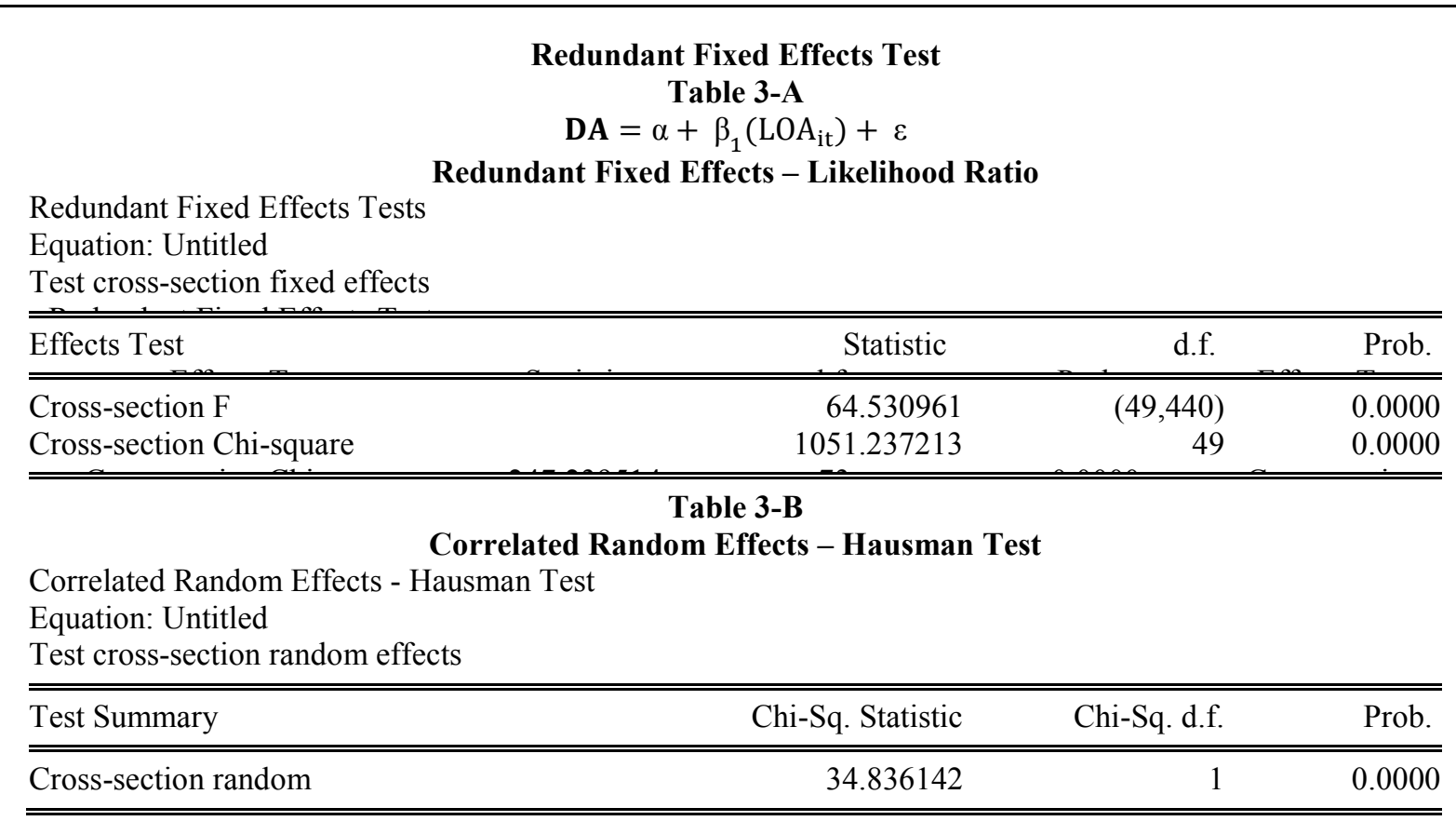

Table 3-C

Dependent Variable: DA

Method: Panel EGLS (Cross-section random effects)

Sample: $2004-2013$

Periods included: 10

Cross-sections included: 50

Total panel (balanced) observations: 500

\begin{tabular}{|c|c|c|c|c|}
\hline Variable & Coefficient & Std. Error & t-Statistic & Prob. \\
\hline LOA & 0.147031 & 0.002584 & 4.466929 & 0.0000 \\
\hline R-squared & 0.236824 & \multicolumn{2}{|l|}{ F-statistic } & 32.2916 \\
\hline Adjusted R-squared & 0.223166 & \multicolumn{2}{|c|}{ Prob. (F-statistic) } & 0.0000 \\
\hline
\end{tabular}

The results of panel data are shown in Table 3.3-A, 3.3-B and 3.3-C. Earnings management is used as dependent variable in this study. It is measured by using the proxy of discretionary accruals. Discretionary Accruals are calculated by using the Jones model. The p-value of cross-secession Chi-square is significant $(0.000)$ which suggests to use the fixed effects model rather than common effects model. The Hausman test's p-value is 0.000 which is also significant. It refers to use the fixed effects model rather than the random effects model.

Table $3.3 \mathrm{C}$ reveals the results of LOA with the relation to earning management. Coefficient value of is 0.147. It indicates that one unit change in firm size leads to 0.147 units change in earnings management i.e. DA. Further the p-value of LOA is highly significant which indicates that increase in the value of total assets would cause to enhance the value of discretionary accruals significantly. Total assets include current assets, fixed assets and any intangible assets. These results reveal that increase in the value of these assets cause to enhance the value of discretionary accruals of the company. The results of this model are similar to the study of (Rahmani and Akbari 2013)); (Naz, Bhatti et al.)

The hypothesis of this study was:

$\mathrm{H}_{0}$ There is no significant relationship between Firms size and earning management.

This hypothesis is rejected and alternative hypothesis is accepted because the results of study indicate that there is significant positive relationship between firm size and earnings management.

$\mathrm{R}$-Square represents the value of variation explained by the independent variable. The value of R-Square and adjusted R-Square are 0.23 and 0.22 respectively. It indicates that the log of assets which is the independent variable explains the $23 \%$ variation in dependent variable.

Value of F statistics is 32.29 and the p-value of this test is 0.000 which is also significant and shows the overall significance of the model. Following experts argued on the reason that why large firms manage their earning more as compared to small firms. As per the study of Barton and Simko (2002) large firms have to manage its earning more on account of the more stress from the investors and the analysts. Myers and Skinner (2000) stated that large firms do not show its actual income. Nelson (2002) explained the fact that the earning managed by the large firms is ignored by the auditors. 


\section{Conclusion}

This study was conducted to evaluate the effect of firm size on earnings management of sampled firms in textile sector of Pakistan. Firm size is independent variable in this study. It was measured by using the proxy of log of total assets. Earning management is the dependent variable of this study. Discretionary accruals represent the earning management. Modified Jones Model was used to estimate the discretionary accruals. This model was used because it was found the most widely used, powerful and accepted model for identifying the earning management practices (Dechow et al., 1995).

The data was collected from the annual reports of fifty (50) sampled firms from textile sector for the period of ten years i.e. 2004 to 2013 to check the impact of firm size on earnings management panel data analysis techniques were applied for the purpose of analysis in this study.

The results of this study revealed that there is positive association of firm size with earning management because large firms face more pressure from investors and financial analysts to show positive earning or increase in earnings. In addition to this large firms have more bargaining power to negotiate with auditors, more treatments of a transaction they have available and stronger power of management they have; which make it easier to manipulate the earnings.

In general the findings of this study suggests that the firms that have larger assets, performs more earning management practices. Various parties like financial managers, institutional investors, individual investors and other stakeholders may get benefit from this study to make rational decisions.

\section{REFERENCES}

Ahmadi, M., Arasi, I. S., \& Garajafary, M. (2012). Studying the relationship between working capital management and profitability at Tehran stock exchange: A case study of food industry. Research Journal of Applied Sciences, Engineering and Technology, 4(13), 1868-1874.

Alves, S. M. (2011). The effect of the board structure on earnings management: evidence from Portugal. Journal of Financial Reporting and Accounting, 9(2), 141-160.

Attari, M. A., \& Raza, K. (2012). The Optimal Relationship of Cash Conversion Cycle with Firm Size and Profitability. International Journal of Academic Research in Business and Social Sciences, 2(4), 189-203.

Ball, R., \& Shivakumar, L. (2006). The role of accruals in asymmetrically timely gain and loss recognition. Journal of accounting research, 207-242.

Barton, J., \& Simko, P. J. (2002). The balance sheet as an earnings management constraint. The accounting review, 77(s-1), 1-27.

Burgstahler, D., \& Dichev, I. (1997). Earnings management to avoid earnings decreases and losses. Journal of accounting and economics, 24(1), 99-126.

Chavis, L. W., Klapper, L. F., \& Love, I. (2009). Entrepreneurial finance around the world: the impact of the business environment on financing constraints. Working Paper, University of North Carolina and The World Bank.

Dechow, P. M., \& Dichev, I. D. (2002). The quality of accruals and earnings: The role of accrual estimation errors. The accounting review, 77(s-1), 35-59.

Dechow, P. M., Sloan, R. G., \& Sweeney, A. P. (1995). Detecting earnings management. Accounting review, $193-$ 225.

Francis, J. R., Maydew, E. L., \& Sparks, H. C. (1999). The role of Big 6 auditors in the credible reporting of accruals. Auditing: A Journal of Practice \& Theory, 18(2), 17-34.

Gong, G., Li, L. Y., \& Xie, H. (2009). The association between management earnings forecast errors and accruals. The Accounting Review, 84(2), 497-530.

Healy, P. M. and J. M. Whalen: 1999, 'A Review of the Earnings Management Literature and Its Implications for Standard Setting', Accounting Horizons 12 (December), 365-384.

Hribar, P. and N. T. Jenkins (2004). "The effect of accounting restatements on earnings revisions and the estimated cost of capital." Review of accounting studies 9(2-3): 337-356.

Jensen, M.C. and W.H. Mcekling, 1976, Theory of the firm: Managerial behavior, agency costs and ownership structure, Journal of Financial Economics 3, 305-360.

Kim, Y., Liu, C., \& Rhee, S. G. (2003). The effect of firm size on earnings management. Collage of Business Administration University of Hawaii.

Kim, Y., Liu, C., \& Rhee, S. G. (2003). The relation of earnings management to firm size. Social Science Research Network.

Llukani, T. (2013). Earnings management and firm size: An empirical analyze in Albanian market; European Scientific Journal 9 (16).

Matsunaga, S. R., \& Park, C. W. (2001). The effect of missing a quarterly earnings benchmark on the CEO's annual bonus. The Accounting Review, 76(3), 313-332.

McNichols, M. F. (2002). Discussion of the quality of accruals and earnings: The role of accrual estimation 
errors. The accounting review, 77(s-1), 61-69.

Moss, J. D. and B. Stine (1993). "Cash conversion cycle and firm size: a study of retail firms." Managerial Finance 19(8): 25-34

Myers, J. N., Myers, L. A., \& Skinner, D. J. (2007). Earnings momentum and earnings management. Journal of Accounting, Auditing \& Finance, 22(2), 249-284.

Myers, J. N., Myers, L. A., \& Skinner, D. J. (2007). Earnings momentum and earnings management. Journal of Accounting, Auditing \& Finance, 22(2), 249-284.

Naz, I., Bhatti, K., Ghafoor, A., \& Husein, H. (2011). Impact of firm size and capital structure on earnings management: Evidence from Pakistan. International Journal of Contemporary Business Studies, 2(12), 22-31.

Nelson, M. W., Elliott, J. A., \& Tarpley, R. L. (2002). Evidence from auditors about managers' and auditors' earnings management decisions. The accounting review, 77(s-1), 175-202.

Osazevbaru, H. O. (2012). Creative Accounting and Firm's Market Value in Nigeria. Kuwait Chapter of Arabian Journal of Business and Management Review, 2(3), 38-50.

Paiva, I. C. and I. Lourenço (2013). "The Effect of Size on the Level of Earnings Management in Family Firms. Available at SSRN 2286757.

Park, Y. W. and H.-H. Shin (2004). "Board composition and earnings management in Canada." Journal of corporate Finance 10(3): 431-457.

Peni, E. and S. Vähämaa (2010). Female executives and earnings management." Managerial Finance 36(7): 629645.

Rahmani, S. and M. A. Akbari (2013). "Impact of Firm Size and Capital Structure on Earnings Management: Evidence from Iran."

Rahmani, S., \& Akbari, M. A. (2013). Impact of Firm Size and Capital Structure on Earnings Management: Evidence from Iran. World of Sciences Journal, 1(17), 59-71.

Shah, S. Z. A., Butt, S. A. \& Hassan A. (2009). Corporate Governance and Earnings Management an Empirical Evidence Form Pakistani Listed Companies, European Journal of Scientific Research, ISSN 1450-216X Vol.26 No.4, pp.624-638,

Shaheen, S. and Q. A. Malik (2012). The impact of capital intensity, size of firm and profitability on debt financing in textile industry of Pakistan." Interdisciplinary Journal of Contemporary Research in Business 3(10).

Siregar, S. V. and S. Utama (2008). Type of earnings management and the effect of ownership structure, firm size, and corporate-governance practices: Evidence from Indonesia. The International Journal of Accounting 43(1): 1-27.

Swastika, D. L. T. (2013). Corporate governance, firm size, and earning management: Evidence in Indonesia stock exchange. IOSR Journal of Economics and Finance (IOSR-JEF), 10(4), 77-82.

Tabassum, N., Kaleem, A., \& Nazir, M. S. (2013). Impact of Real Earnings Management on Subsequent Financial Performance. Middle-East Journal of Scientific Research, 17(4), 551-560.

Verrecchia, R. E. (1983). Discretionary disclosure. Journal of accounting and economics, 5, 179-194.

Warfield, T. D., Wild, J. J., \& Wild, K. L. (1995). Managerial ownership, accounting choices, and informativeness of earnings. Journal of accounting and economics, 20(1), 61-91.

Yuan, H., \& Zafar, N. (2010). Earnings management and dividend policy an empirical comparison between Pakistani listed companies and Chinese listed companies. International Research Journal of Finance and Economics, (35). 